\title{
Synthesis, Characterization and Anti-Microbial Studies of Metal (II) Complexes of Schiff Base Derived from Condensation of 2-Thiophene Carboxyldehyde and 2-Aminothiophenol
}

\section{Umar Dalha and Aminu Ahmad}

Chemistry Department, Kano University of Science and Technology, Wudil, Nigeria e-mail: daddyjahun@gmail.com

\begin{abstract}
Schiff base ligand derived from condensation of 2-aminothiophenol and 2-thiophene carboxyldehy was synthesized and used for the preparation of $\mathrm{Cr}(\mathrm{II}), \mathrm{Mn}$ (II) and $\mathrm{Co}$ (II), complexes. The synthesized ligand and complexes were analyzed by decomposition temperature, solubility, magnetic susceptibility, molar conductance and infrared spectra. The decomposition temperatures of the complexes are in the range of $128-221^{\circ} \mathrm{C}$. Molar conductance values are in the range of $6.07-9.10 \mathrm{ohm}^{-1} \mathrm{~cm}^{2} \mathrm{~mol}^{-1}$. New bands appeared in the IR spectra of the complexes in the range of $511-552 \mathrm{~cm}^{-1}$ and $438-473 \mathrm{~cm}^{-1}$ which indicate $v(\mathrm{M}-\mathrm{N})$ and $v(\mathrm{M}-\mathrm{S})$ vibrations respectively. Magnetic susceptibility measurement indicated that all complexes are paramagnetic while solubility test revealed that all complexes and ligand are soluble in DMSO. The analytical data show the formation of 2:1 metal to ligand ratio for all complexes and suggested the formula $\left[\mathrm{ML}_{2}\right] \cdot \mathrm{nH}_{2} \mathrm{O}$.The ligand and metal chelates have been studied for microbial activity using well diffusion method against selected bacteria and fungi. The results signify that metal complexes inhibit more compared with Schiff base ligand against the same test organisms.
\end{abstract}

\section{Introduction}

Schiff base were first discovered in 1864 by a German chemist, Nobel prize winner Hugo Schiff and named after his name. They are the products yielded from condensation

Received: November 22, 2020; Accepted: December 12, 2020

Keywords and phrases: 2-aminothiophenol, 2-thiophene carboxyldehy, amino acid, Schiff base, antimicrobial, mole fraction, solubility.

Copyright (C) 2021 Umar Dalha and Aminu Ahmad. This is an open access article distributed under the Creative Commons Attribution License, which permits unrestricted use, distribution, and reproduction in any medium, provided the original work is properly cited. 
reaction of primary amines and carbonyl compounds. When carbonyl compound (aldehyde or ketone) is condensed with a primary amine, a Schiff base is produced, which is a compound containing azomethine group, R-C=N-. Schiff base have the general structure of $\mathrm{R}^{3} \mathrm{~N}=\mathrm{CR}^{1} \mathrm{R}^{2}$ (Figure 1.1). Here $\mathrm{R}$ and $\mathrm{R}^{\prime}$ are aryl, alkyl, cycloalkyl or heterocyclic groups, which may be variously substituted.

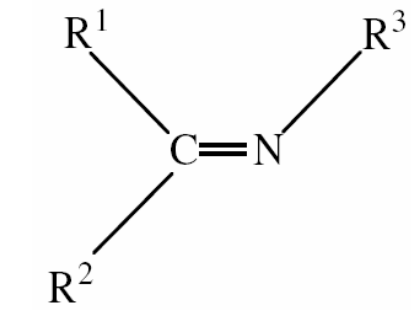

$$
\mathrm{R}^{1}, \mathrm{R}^{2} \text { and } \mathrm{R}^{3}=\text { Aryl or alkyl group }
$$

Figure 1.1. General structure of Schiff base.

Schiff bases are considered as very important class of organic compounds, which have wide applications in many biological aspects. Transition Metal complexes of Schiff bases are thoroughly studied and also have applications in catalysis and organic synthesis. They are used as pigments and dyes, intermediates in organic synthesis, and as polymer stabilizers. The azomethine group present in the Schiff bases ligand is responsible for antitumor, antibacterial, antifungal and herbicidal activities.

Schiff base ligands are widely used as ligands due to the ease of their formation and remarkable versatility, and therefore, they have played an important role in the development of coordination chemistry as they readily form stable complexes with most of the transition metals. Schiff bases may be bidentate, tridentate, tetradentate or polydentate ligands capable of forming very stable c Metal complexes of $\mathrm{Ni}(\mathrm{II}), \mathrm{Co}(\mathrm{II})$, $\mathrm{Cu}(\mathrm{II}), \mathrm{Mn}(\mathrm{II})$, and $\mathrm{Zn}$ (II) with a Schiff base derived from 3-ethoxysalicyldehyde and 2(2-aminophenyl) 1-H-benzimidazole were synthesized. The resulting complexes were characterized by elemental analysis, Magnetic moment measurement, conductivity measurement, IR, UV-Visible, ${ }^{1} \mathrm{H}$ NMR and mass spectra studies. An octahedral geometry was proposed to all the metal complexes. Antimicrobial activity of the ligand and its metal complexes were studied against two gram-negative of Escherichia coli, Pseudomonas florescence and two gram-positive bacteria of Bacillus subitilis, Staphylococcus aureus. The activity result showed that the metal complexes were more potent than the free ligand. 
A Schiff base derived from p-hydroxybenzaldehyde and 4-aminobenzoic acid. The transition metal complexes of $\mathrm{Ni}(\mathrm{II}), \mathrm{Cu}(\mathrm{II}), \mathrm{Co}(\mathrm{II}), \mathrm{Cd}(\mathrm{II}), \mathrm{Zn}$ (II) and $\mathrm{Cr}$ (III) were prepared separately with the Schiff base, which were used as ligand. Several physical tools, in particular; elemental analysis, molar conductivity, magnetic susceptibility, infrared spectroscopy (IR), electronic absorption spectroscopy (ESR) to investigate the chemical structure of the prepared transition metal complexes. The elemental analysis data show the formation of $1: 2\left[\mathrm{M}^{1}: 2 \mathrm{~L}\right]$ and $1: 3\left[\mathrm{M}^{2}: 3 \mathrm{~L}\right]$ complexes of the formula of $\mathrm{M}^{2+} \mathrm{L}_{2}$ and $\mathrm{M}^{3+} \mathrm{L}_{3}$, respectively where $\mathrm{M}^{2+}=\mathrm{Ni}(\mathrm{II}), \mathrm{Cu}(\mathrm{II}), \mathrm{Co}(\mathrm{II}), \mathrm{Cd}(\mathrm{II}), \mathrm{Zn}$ (II) and $\mathrm{M}^{3+}=$ $\mathrm{Cr}$ (III) and $\mathrm{L}=\mathrm{Schiff}$ base (SB). The molar conductance (conductivity) measurements revealed that all the complexes are non-electrolyte in nature. The infrared (IR) spectral studies indicated the binding sites of the Schiff base ligand with the transition metal ions. The magnetic susceptibility measurements and electronic spectral results supported the predicted coordination geometry of the complexes and magnetic properties (para or diamagnetic nature) of the complex compounds. The free Schiff base and its complexes have been tested for their antimicrobial activities against several human pathogenic (two gram-positive and two gram-negative) bacteria. The results obtained shows that the complex compounds exhibit moderate to strong antimicrobial activity compared with kanamycin and ampicillin.

$\mathrm{Mn}(\mathrm{II}), \mathrm{Co}(\mathrm{II}), \mathrm{Ni}(\mathrm{II}), \mathrm{Cu}(\mathrm{II})$ and $\mathrm{Zn}(\mathrm{II})$ complexes with a tridentate Schiff base were prepared by condensation of ethyl 2-amino-4,5,6,7-tetrahydro-1-benzothiophene-3carboxylate with 4-hydroxypent-3-en-2-one were synthesized and characterized by elemental analysis, molar conductance measurements, magnetic susceptibility, UV-Vis, IR, EPR and NMR spectral data,

\section{Materials and Methods}

Reagents are of analytical grade purity and were obtained from Sigma Aldrich chemical limited. The glass wares used were washed thoroughly with detergent, rinsed with distilled water and dried in an oven. Melting point and decomposition temperature were determined using Gallenkamp melting point apparatus. Molar conductivity measurement was carried out using Jenway conductivity meter model 4010, while magnetic susceptibility measurement was done on MBS MKI magnetic susceptibility balance at $25^{\circ} \mathrm{C}$. IR spectral analysis was carried out using FTIR Cary 630 (Agilent Technology) model in the range of $4000-400 \mathrm{~cm}^{-1}$. Bacterial and fungal isolates were obtained and identified at the Department of Microbiology, Kano University of Science and Technology, Wudil. 


\subsection{Methods}

\subsubsection{Preparation of Schiff base}

The Schiff base were prepared by mixing a solution of 2-aminothiophenol (2.50g, 0.1 mole $)$ in $25 \mathrm{ml}$ of ethanol with 2-thiophene carboxyldehyde $(2.24 \mathrm{~g}, 0.1 \mathrm{~mole})$ in the same solvent. The reaction mixture was left under refluxed for 2 hours. The solid yellow product formed was separated by filtration, purified by crystallization from ethanol, and then dried in a desiccator over anhydrous calcium chloride.

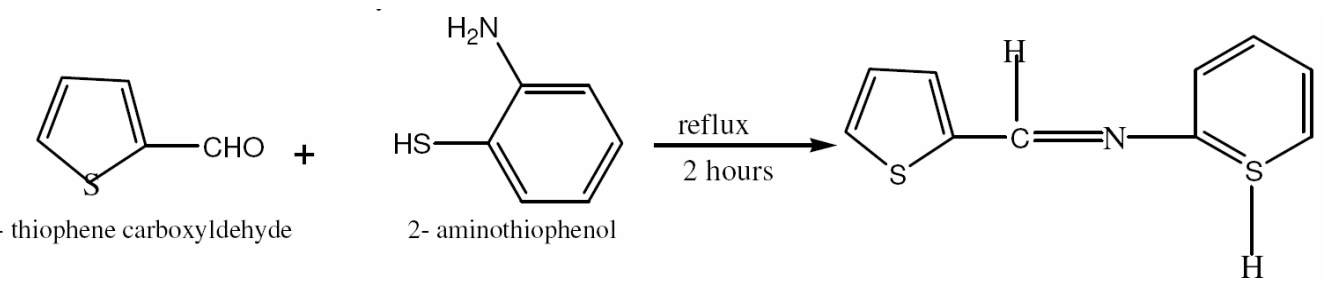

Scheme 3.1. Preparation of the Schiff base.

\subsubsection{Preparation of the metal complexes}

The metal complex of Schiff base was prepared by the addition of a solution of appropriate metal chloride $(1 \mathrm{mmol})$ in an ethanol water-mixture $(1: 1,25 \mathrm{ml})$ to the solution of schiff base $(0.219 \mathrm{~g}, 2 \mathrm{mmol})$ in the same solvent $(25 \mathrm{ml})$. The resulting mixture was stirred under reflux for 1hour upon the complex precipitated and collected by filtration and washed with a 1:1 ethanol-water mixture.

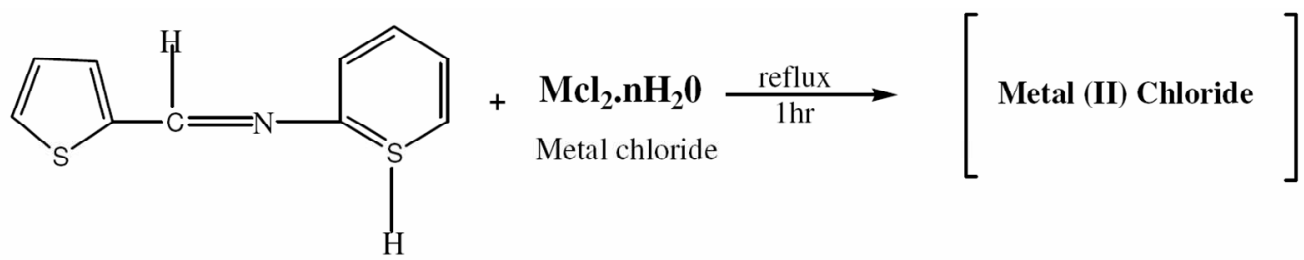

Scheme 3.2. Preparation of Metal(II) Complex.

\subsection{Solubility Test}

The solubility test of the Schiff base and the metal complexes was carried out in some solvents, ethanol, methanol, dimethylsulphoxide (DMSO), dimethylformamide (DMF), n-hexane, diethyl ether, chloroform and distilled water. Small amount of Schiff base and metal(II) complexes were each added into the test tube followed by addition of the solvent. Their solubility was observed after shaking the test tube. 


\subsection{Melting Point/Decomposition Temperature}

The melting point of the Schiff base and the decomposition temperature of the metal complexes were carried by taking small amount of each into a capillary tube. The tube was inserted into the Gallenkamp apparatus, the temperature at which the ligand melt and that which the complexes decompose were taken and recorded

\subsection{Conductivity Measurement}

$0.003 \mathrm{M}$ solutions of the metal complexes were prepared in DMSO and the molar conductance was determined by Janway, 4010 conductivity meter. All measurements were carried out at room temperature; the molar conductance value was obtained from the relation

$$
\text { Molar conductance }=\frac{1000}{C} \times K
$$

where $\mathrm{C}=$ Molar concentrations

$\mathrm{K}=$ specific conductance.

\subsection{Magnetic Susceptibility Measurement}

The magnetic susceptibility of the metal complexes was obtained from magnetic susceptibility balance. Each separate sample of the metal complex was placed into a capillary tube and then inserted into the magnetic susceptibility balance, the readings was then recorded. The gram magnetic moment is calculated using the relation

$$
X_{g}=\frac{C L\left(R-R_{0}\right)}{10^{9} M} .
$$

\subsection{Determination of Percentage of Water of Crystallization in the Complexes}

About $0.2 \mathrm{~g}$ of each of the metal complexes was measured into a watch glass of known weight and placed in an oven at $1100 \mathrm{C}$ until a constant weight was obtained. The percentage composition of water in the complex was calculated using the below formula:

$$
\frac{\text { Weight lost }}{\text { Weight of the complex taken }} \times 100 \text {. }
$$




\subsection{Determination of Percentage of Metal Ions in the Complexes}

\subsubsection{Digestion of metal complex}

About $0.2 \mathrm{~g}$ of each of the metal(II) complex was placed in a $100 \mathrm{~cm}^{3}$ beaker containing $25 \mathrm{~cm}^{3}$ of distilled water to which $5 \mathrm{~cm}^{3}$ of concentrated acid was added and then heated to about dryness. The contents in the beaker were allowed to cool to room temperature and $25 \mathrm{~cm}^{3}$ of distilled water was added and the mixture was stirred before the filtrate was collected which contains the metal ions.

\subsubsection{Estimation of chromate in chromate(II) complex}

The filtrate of the digested chromate(II) complex was diluted to $100 \mathrm{~cm}^{3}$ with distilled water. Pyridine was added until the colour changed to intense blue followed by $0.5 \mathrm{~g}$ of ammonium thiocyanate with stirring and then allowed to stand for few minutes, chromate was precipitated as dipyridine chromate(II) thiocyanate $\left[\mathrm{Cr}\left(\mathrm{C}_{5} \mathrm{H}_{5} \mathrm{~N}\right)_{2}\right](\mathrm{SCN})_{2}$ which was filtered, washed and dried.

\subsubsection{Estimation of manganese in manganese(II) complex}

Water was added to the filtrate obtained from the digested manganese (II) complex to $100 \mathrm{~cm}^{3}$ level in $250 \mathrm{~cm}^{3}$ conical flask. Dilute ammonia was added to neutralize the filtrate followed by $10 \mathrm{~g}$ ammonia Chloride, excess diammonium hydrogen phosphate $\left(\mathrm{NH}_{4}\right)_{2} \mathrm{HPO}_{4}$ and few drops of 1:3 hydrochloric acid. The solution was heated to $90-95^{\circ} \mathrm{C}$ followed by drop wise addition of dilute aqueous ammonia with constant stirring until a precipitate began to form. The addition of ammonia was stop immediately while the heating and stirring continued to ensure that the precipitate formed crystallize as $\mathrm{MnNH}_{4} \mathrm{PO}_{4} \mathrm{H}_{2} \mathrm{O}$. Few drops of aqueous ammonia was added with stirring for completion of precipitation. The beaker and its content were allowed to cool to room temperature, then the precipitate was filtered and washed with $1 \%$ ammonium nitrate solution. The product was heated to constant weight.

\subsubsection{Estimation of cobalt in cobalt(II) complex}

About $8 \mathrm{~cm}^{3}$ of distilled water was added to the filtrate obtained from digested cobalt(II) complex. Then $0.7 \mathrm{~g}$ of ammonium thiocyanate was added to the mixture and boiled, $20 \mathrm{~cm}^{3}$ of pyridine was added after which the source of heat was removed immediately. The solution was stirred for 5 seconds and allowed to cool to room temperature. Shiny red crystals of the complex separated. The precipitate was filtered, washed with distilled water dried and weight as dipyridine cobalt(II) thiocyanate $\left[\mathrm{Co}\left(\mathrm{C}_{5} \mathrm{H}_{5} \mathrm{~N}\right)_{2}\right](\mathrm{SCN})_{2}$. 


\subsection{Determination of the Metal to Ligand Ratio in the Complex Compounds using Job's Method of Continuous Variation}

The number of coordinated Schiff base ligand in the metal ion were determined by Job's method in which 3 millimolar solution of the ligand and the metal(II) chloride were separately prepared. The following ligand to metal salt $(\mathrm{mL}) ; 1: 15,3: 13,5: 11,7: 9,9: 7$, 11:5, 13:3, 15:1 were taken from the ligand solution and each of the metal complexes. A total volume of $16 \mathrm{ml}$ was maintained (in the above order) throughout the process and mole fraction of the ligand was calculated in each mixture. The solutions of the metal chloride (blank) were scanned to obtained wave length of maximum absorption $\left(\lambda_{\max }\right)$ for each metal ion. The spectrophotometer was set at $\lambda_{\max }$ before taking the absorbance value. A plot of absorbance against mole fraction of the ligand, the number of coordinated ligand was determined using the following relation:

$$
\bar{n}=\frac{X_{i}}{1-X_{i}}
$$

where:

$\bar{n}=$ number of coordinated ligand at maximum absorbance

$X_{i}=$ mole fraction at maximum absorbance.

\subsection{Determination of Empirical Formular}

The composition of each complex was determined from the known percentage of the metal ion and water content in the complex. The percentage composition of the ligand was obtained by adding percentage composition of the metal and water in the complex and subtracted from 100 to get that of ligand. The empirical formula of each of the complex was calculated using the percentage composition of the species involved.

\subsection{Anti-bacterial Studies}

The antibacterial activity of the Schiff base ligand and its metal complexes was carried out by using bacterial isolates of Staphylococcus aureus, streptococcus pneumoniae, and Escherichia coli. The suspension of each microorganism was smeared on the surface of the solidified Muller-Hinton Agar (MHA) already poured into petri dishes. The Schiff base and the metal Complexes were separately dissolved in DMSO so as to have three distinct concentrations $(60 \mu \mathrm{g} / \mathrm{disc}, 30 \mu \mathrm{g} / \mathrm{disc}$ and $15 \mu \mathrm{g} / \mathrm{disc})$ through serial dilution and placed on the surface of the culture media, incubated at $37^{\circ} \mathrm{C}$ for 24 
hours. Activities were determined by measuring $(\mathrm{mm})$ the diameter of the zone of inhibition and compared with a standard drug (Ciprofloxacin).

\subsection{Anti-fungal Studies}

The antifungal activity of the Schiff base ligand and that of its metal complexes were tested against three pathogenic fungi; Candida albicans, Aspergillus flavus, and Aspergillus fumigatus, using disc diffusion method. Ketoconazole was used as standard fungicide and DMSO was used as a negative control. The fungal suspension was smeared on the solidified Potato Dextrose Agar (PDA) already poured into petri dishes. The Schiff base and the metal Complexes were separately dissolved in DMSO to have three different concentrations $(60 \mu \mathrm{g} / \mathrm{disc}, 30 \mu \mathrm{g} / \mathrm{disc}$ and $15 \mu \mathrm{g} / \mathrm{disc})$ per well. They were placed on the surface of the culture media and allowed to stand at room temperature for good 48 hours. Activities were determined by measuring $(\mathrm{mm})$ the diameter of the zone of inhibition and compared with the standard.

\section{Results and Discussions}

\subsection{Results}

Results of the physical properties, characterization and microbial activities of the prepared Schiff base ligand and its metal (II) complexes are presented in the following tables.

Table 3.1. Physical properties of Ligand and its metal (II) Complexes.

\begin{tabular}{lllll}
\hline Compound & Colour & \% yield & M.P $\left({ }^{\mathbf{0}} \mathbf{C}\right)$ & D.Temp $\left({ }^{\mathbf{O}} \mathbf{C}\right)$ \\
\hline Ligand & Yellow & 79 & 128 & - \\
{$\left[\mathrm{CrL}_{2}\right]$} & Orange & 57 & - & 194 \\
{$\left[\mathrm{MnL}_{2}\right]$} & Brown & 56 & - & 201 \\
{$\left[\mathrm{CoL}_{2}\right]$} & Black & 61 & - & 188 \\
\hline
\end{tabular}

Where; $\mathrm{L}=\mathrm{C}_{11} \mathrm{H}_{9} \mathrm{NS}_{2}$, M.P = Melting Point, D. Temp.= Decomposition Temperature 
Table 3.2. Solubility Test of Schiff base Ligand and its Metal Complexes.

\begin{tabular}{lllll}
\hline Solvents & Ligand & {$\left[\mathrm{CrL}_{2}\right]$} & {$\left[\mathrm{MnL}_{2}\right]$} & {$\left[\mathrm{CoL}_{2}\right]$} \\
\hline Water & IS & IS & IS & IS \\
Methanol & S & S & S & S \\
Ethanol & S & S & S & S \\
n-hexane & IS & IS & IS & IS \\
Chloroform & S & IS & SS & SS \\
Diethylether & S & SS & S & SS \\
DMF & S & S & S & S \\
DMSO & S & S & S & S \\
\hline
\end{tabular}

$$
\mathrm{L}=\mathrm{C}_{11} \mathrm{H}_{9} \mathrm{NS}_{2}
$$

DMSO=Dimethylsulfoxide,

DMF=Dimethylformamide,

$\mathrm{CCl} 4$ = Carbontetrachloride

$\mathrm{S}=$ Soluble

SS = Slightly Soluble

$\mathrm{IS}=$ Insoluble

Table 3.3. IR Spectra of the Schiff base and its Metal(II) Complexes.

\begin{tabular}{lccccc}
\hline Compounds & $\mathbf{V}(\mathbf{C}=\mathbf{N}) \mathbf{c m}^{-\mathbf{1}}$ & $\mathbf{V}(\mathbf{M}-\mathbf{S}) \mathbf{c m}^{\mathbf{- 1}}$ & $\mathbf{V}(\mathbf{M - N}) \mathbf{c m}^{-\mathbf{1}}$ & $\mathbf{V}(\mathbf{C}-\mathbf{S}-\mathbf{C}) \mathbf{c m}^{-\mathbf{1}}$ & $\mathbf{V}(\mathbf{C}-\mathbf{S}) \mathbf{c m}^{-\mathbf{1}}$ \\
\hline Ligands & 1689 & - & - & 852 & - \\
{$\left[\mathrm{CrL}_{2}\right]$} & 1678 & 473 & 543 & 873 & 739 \\
{$\left[\mathrm{MnL}_{2}\right]$} & 1607 & 438 & 511 & 840 & 742 \\
{$\left[\mathrm{CoL}_{2}\right]$} & 1640 & 452 & 552 & 829 & 706 \\
\hline
\end{tabular}

$\mathrm{L}=\mathrm{C}_{11} \mathrm{H}_{9} \mathrm{NS}_{2}$ 
Table 3.4. Conductivity Measurement Data of 10-3 M Metal(II) Complexes in DMSO.

\begin{tabular}{|c|c|c|}
\hline Complexes & $\begin{array}{l}\text { Electrical Conductivity } \\
\left(\mathbf{o h m}^{-1} \mathbf{c m}^{-1}\right) \times 10^{-6}\end{array}$ & $\begin{array}{l}\text { Molar Conductance } \\
\left(\mathrm{ohm}^{-1} \mathbf{c m}^{2} \mathbf{m o l}^{-1}\right)\end{array}$ \\
\hline$\left[\mathrm{CrL}_{2}\right]$ & $41.1 \times 10^{-6}$ & 9.1 \\
\hline$\left[\mathrm{MnL}_{2}\right]$ & $37.81 \times 10^{-6}$ & 8.39 \\
\hline$\left[\mathrm{CoL}_{2}\right]$ & $18.23 \times 10^{-6}$ & 6.07 \\
\hline
\end{tabular}

Table 3.5. Magnetic Susceptibility Data of Metal(II) Schiff base Complexes.

\begin{tabular}{lcll}
\hline Complex & $\boldsymbol{\mu}_{\text {eff }}($ B.M $)$ & Magnetic Property & $\begin{array}{l}\text { Number of unpaired } \\
\text { electrons }\end{array}$ \\
\hline$\left[\mathrm{CrL}_{2}\right]$ & 4.38 & Paramagnetic & 6 \\
{$\left[\mathrm{MnL}_{2}\right]$} & 5.50 & Paramagnetic & 5 \\
{$\left[\mathrm{CoL}_{2}\right]$} & 4.90 & Paramagnetic & 3 \\
\hline
\end{tabular}

$\mathrm{L}=\mathrm{C}_{11} \mathrm{H}_{9} \mathrm{NS}_{2}$

Table 3.6. Determination of Water of Crystallization in the Complexes.

$\begin{array}{lll}\text { Complex } \quad \text { Weight Lost }(\mathrm{g}) \quad \text { Percentage }(\%) & \begin{array}{l}\text { Number of Water of } \\ \text { Crystallization }\end{array}\end{array}$

\begin{tabular}{lccc}
\hline$\left[\mathrm{CrL}_{2}\right]$ & 0.022 & 11.00 & 3 \\
{$\left[\mathrm{MnL}_{2}\right]$} & 0.024 & 12.00 & 3 \\
{$\left[\mathrm{CoL}_{2}\right]$} & 0.015 & 7.50 & 2 \\
\hline
\end{tabular}

$\mathrm{L}=\mathrm{C}_{11} \mathrm{H}_{9} \mathrm{NS}_{2}$ 
Table 3.7. Percentage (\%) of Metal ion in the Metal(II) Schiff base Complexes.

Complex

$\left[\mathrm{CrL}_{2}\right]$

$\left[\mathrm{MnL}_{2}\right]$

$\left[\mathrm{CoL}_{2}\right]$

$\mathrm{L}=\mathrm{C}_{11} \mathrm{H}_{9} \mathrm{NS}_{2}$

\section{Percentage (\%)}

10.36

10.88

13.01

Table 3.8. Emperical formula of the Complexes.

\begin{tabular}{llllll}
\hline Compound & $\%$ of Metal & $\begin{array}{l}\% \\
\text { Ligand }\end{array}$ & of $\%$ of Water & $\begin{array}{l}\text { Metal:Ligand } \\
\text { ratio }\end{array}$ & $\begin{array}{l}\text { Empirical } \\
\text { Formular }\end{array}$ \\
\hline $\mathrm{Cr}(\mathrm{II})$ complex & 10.36 & 78.64 & 11.00 & $1: 2$ & {$\left[\mathrm{CrL}_{2}\right] \cdot 3 \mathrm{H}_{2} \mathrm{O}$} \\
$\mathrm{Mn}(\mathrm{II})$ complex & 10.88 & 77.12 & 12.00 & $1: 2$ & {$\left[\mathrm{MnL}_{2}\right] \cdot 3 \mathrm{H}_{2} \mathrm{O}$} \\
$\mathrm{Co}(\mathrm{II})$ complex & 13.01 & 79.49 & 7.50 & $1: 2$ & {$\left[\mathrm{CoL}_{2}\right] \cdot 2 \mathrm{H}_{2} \mathrm{O}$} \\
\hline
\end{tabular}

$\mathrm{L}=\mathrm{C}_{11} \mathrm{H}_{9} \mathrm{NS}_{2}$

Table 3.9.1. Mole Fraction of the Ligand and the Absorbance values for $\mathrm{Cr}^{2+}$ ion at $545 \mathrm{~nm}$.

\begin{tabular}{lll}
\hline $\mathbf{C r}^{2+}: \mathbf{L}$ Ratio & Mole Fraction & Absorbance \\
\hline $1: 15$ & 0.0625 & 0.1010 \\
$3: 13$ & 0.1875 & 0.1172 \\
$5: 11$ & 0.3125 & 0.1715 \\
$7: 9$ & 0.43715 & 0.2704 \\
$9: 7$ & 0.5625 & 0.2567 \\
$11: 5$ & 0.68754 & 0.3019 \\
$13: 3$ & 0.8125 & 0.1347 \\
$15: 1$ & 0.9375 & 0.1092 \\
\hline $\mathrm{L}=\mathrm{C}_{11} \mathrm{H}_{9} \mathrm{NS}_{2}$ & & \\
\hline
\end{tabular}


Table 3.9.2. Mole fraction of the ligand and the absorbance values of $\mathrm{Mn}^{2+}$ ion at $620 \mathrm{~nm}$.

\begin{tabular}{lll}
\hline $\mathbf{M n}^{2+}:$ L Ratio & Mole Fraction & Absorbance \\
\hline $1: 15$ & 0.0625 & 0.2118 \\
$3: 13$ & 0.1875 & 0.3240 \\
$5: 11$ & 0.3125 & 0.4106 \\
$7: 9$ & 0.43715 & 0.4892 \\
$9: 7$ & 0.5625 & 0.5160 \\
$11: 5$ & 0.68754 & 0.6697 \\
$13: 3$ & 0.8125 & 0.7211 \\
$15: 1$ & 0.9375 & 0.2248 \\
\hline
\end{tabular}

$\mathrm{L}=\mathrm{C}_{11} \mathrm{H}_{9} \mathrm{NS}_{2}$

Table 3.9.3. Mole Fraction of the Ligand and the Absorbance values for $\mathrm{Co}^{2+}$ ion at $560 \mathrm{~nm}$.

\begin{tabular}{lll}
\hline $\mathbf{C o}^{2+}:$ L Ratio & Mole Fraction & Absorbance \\
\hline $1: 15$ & 0.0625 & 0.2130 \\
$3: 13$ & 0.1875 & 0.2251 \\
$5: 11$ & 0.3125 & 0.2460 \\
$7: 9$ & 0.43715 & 0.2738 \\
$9: 7$ & 0.5625 & 0.3461 \\
$11: 5$ & 0.68754 & 0.3901 \\
$13: 3$ & 0.8125 & 0.2110 \\
$15: 1$ & 0.9375 & 0.1901 \\
\hline
\end{tabular}

$\mathrm{L}=\mathrm{C}_{11} \mathrm{H}_{9} \mathrm{NS}_{2}$ 
Table 3.10. Antibacterial Activity of the Schiff base and its Metal(II) Complexes.

\begin{tabular}{|c|c|c|c|c|c|}
\hline \multirow[t]{2}{*}{ Isolates } & \multirow[t]{2}{*}{ Compounds } & \multicolumn{2}{|c|}{$\begin{array}{l}\text { Zone of } \\
(\mu \mathrm{g} / \mathrm{ml})\end{array}$} & \multirow{2}{*}{$\begin{array}{l}\text { inhibition } \\
15\end{array}$} & \multirow[t]{2}{*}{ Standard } \\
\hline & & 60 & 30 & & \\
\hline \multirow{4}{*}{$\begin{array}{l}\text { Staphylococcus } \\
\text { aureaus }\end{array}$} & Ligand & 9 & 8 & 7 & \\
\hline & {$\left[\mathrm{CrL}_{2}\right]$} & 11 & 9 & 8 & \\
\hline & {$\left[\mathrm{MnL}_{2}\right]$} & 10 & 7 & 6 & \\
\hline & {$\left[\mathrm{CoL}_{2}\right]$} & 14 & 11 & 8 & 29 \\
\hline \multirow{4}{*}{$\begin{array}{l}\text { Streptococcus } \\
\text { pnemoniae }\end{array}$} & Ligand & 8 & 6 & 6 & \\
\hline & {$\left[\mathrm{CrL}_{2}\right]$} & 14 & 11 & 7 & \\
\hline & {$\left[\mathrm{MnL}_{2}\right]$} & 13 & 10 & 8 & \\
\hline & {$\left[\mathrm{CoL}_{2}\right]$} & 10 & 6 & 6 & 19 \\
\hline \multirow[t]{4}{*}{ Eschericia coli } & Ligand & 11 & 9 & 7 & \\
\hline & {$\left[\mathrm{CrL}_{2}\right]$} & 12 & 8 & 6 & \\
\hline & {$\left[\mathrm{MnL}_{2}\right]$} & 14 & 11 & 9 & \\
\hline & {$\left[\mathrm{CoL}_{2}\right]$} & 12 & 10 & 7 & 24 \\
\hline
\end{tabular}

$\mathrm{L}=\mathrm{C}_{11} \mathrm{H}_{9} \mathrm{NS}_{2}$

Table 3.11. Antifungal Activity of the Schiff base and its Metal(II) Complexes.

\begin{tabular}{llllll}
\hline \multirow{2}{*}{ Isolates } & Compounds & \multicolumn{3}{c}{ Zone of inhibition $(\boldsymbol{\mu g} / \mathbf{m l})$} & Standard \\
& & $\mathbf{6 0}$ & $\mathbf{3 0}$ & $\mathbf{1 5}$ & \\
\hline Aspergillus & Ligand & 18 & 16 & 10 & \\
fumigates & {$\left[\mathrm{CrL}_{2}\right]$} & 18 & 15 & 12 & 31 \\
& {$\left[\mathrm{MnL}_{2}\right]$} & 18 & 16 & 11 & \\
& {$\left[\mathrm{CoL}_{2}\right]$} & 20 & 15 & 12 & \\
Aspergillus flavus & $\mathrm{Ligand}$ & 13 & 10 & 7 & \\
& {$\left[\mathrm{CrL}_{2}\right]$} & 16 & 10 & 8 & 26 \\
& {$\left[\mathrm{MnL}_{2}\right]$} & 15 & 11 & 8 & \\
& {$\left[\mathrm{CoL}_{2}\right]$} & 15 & 13 & 9 & \\
\hline
\end{tabular}




\begin{tabular}{llllll} 
Candida albicans & Ligand & 11 & 8 & 6 & \\
& {$\left[\mathrm{CrL}_{2}\right]$} & 6 & 6 & 6 & \\
& {$\left[\mathrm{MnL}_{2}\right]$} & 14 & 11 & 8 & 29 \\
{$\left[\mathrm{CoL}_{2}\right]$} & 11 & 6 & 6 & \\
\hline
\end{tabular}

$\mathrm{L}=\mathrm{C}_{11} \mathrm{H}_{9} \mathrm{NS}_{2}$

\subsection{Discussion}

The Schiff base ligand was prepared by condensation of 2-aminothiophenol and 2thiophene carboxyldehyde to obtain yellow crystal with high yield $(75 \%)$ and melting point of $128^{\circ} \mathrm{C}$ (Table 3.1). The metal complexes, $\mathrm{Cr}(\mathrm{II}), \mathrm{Mn}(\mathrm{II})$ and $\mathrm{Co}(\mathrm{II})$, complexes were synthesized and found to be of various colors with percentage composition of $61 \%$, $56 \%$, and 58\% The decomposition temperature of the metal complexes range from $188^{\circ} \mathrm{C}-221^{\circ} \mathrm{C}$ showing that the decomposition temperature of the metal (II) complexes is higher than that of melting point of the ligand indicating that complexation has taken place.

The solubility test carried out on the Schiff base showed that the Schiff base was soluble in methanol, ethanol, DMSO, DMF, diethylether, and chloroform but insoluble only in water and n-hexane. However, the metal (II) complexes were soluble in ethanol, methanol, DMSO and DMF, but insoluble in water and n-hexane while slightly soluble in diethylether and chloroform (Table 3.2).

The infrared spectral results of the ligand shows a band at $1689 \mathrm{~cm}^{-1}$ assigned to azomethine $v(\mathrm{C}=\mathrm{N})$ vibration, this confirms condensation between amino group of 2aminothiophenol and aldehyde group of 2-thiophene carboxyldehyde in the formation of Schiff base. The infrared spectral data of the Schiff base ligand and its metal complexes were listed in Table 3.3.

The molar conductance of each of the metal(II) complex was measured in dimethylsulfoxide (DMSO) . The values obtained were in the range of $6.07-16.12 \mathrm{ohm}^{-}$ ${ }^{1} \mathrm{~cm}^{2} \mathrm{~mol}^{-1}$ (Table 4.4) which are relatively low, indicating the non-electrolytic nature of the metal complexes. The molar conductance ranges for non-electrolyte metal complexes in DMSO is $1-50 \mathrm{ohms}^{-1} \mathrm{~cm}^{2} \mathrm{~mol}^{-1}$.

Magnetic susceptibility measurement values for $\mathrm{Cr}(\mathrm{II}), \mathrm{Mn}$ (II) and $\mathrm{Co}(\mathrm{II})$ complexes at room temperature are in Table 4.5. The values for $\mathrm{Cr}$ (II), $\mathrm{Mn}$ (II) and $\mathrm{Co}$ (II) complexes 
indicated that they are all paramagnetic with both shows the present of unpaired electrons.

The metal-ligand ratio was determined by using Job's method of continuous variation (UV-Visible). The results were presented in Tables $3.5-3.7$. They revealed that the metal-ligand ratio was 1:2. Gravimetric analysis was used for the determination of the percentage of metal(II) ions in the complexes (Table 3.7). The metal (II) Schiff base complexes show variation in the co-ordination number of water molecules. $\mathrm{Cr}$ (II) and $\mathrm{Mn}$ (II) has three molecules of water each, while Co(II) has two water molecules. The empirical formulae of the complexes were determined from known values of percentage composition of metals, Schiff base and water of crystallization. The results revealed that the metal-ligand was 1:2 for all the complexes and suggested the formula $\left[\mathrm{ML}_{2}\right] \cdot \mathrm{nH}_{2} \mathrm{O}$.

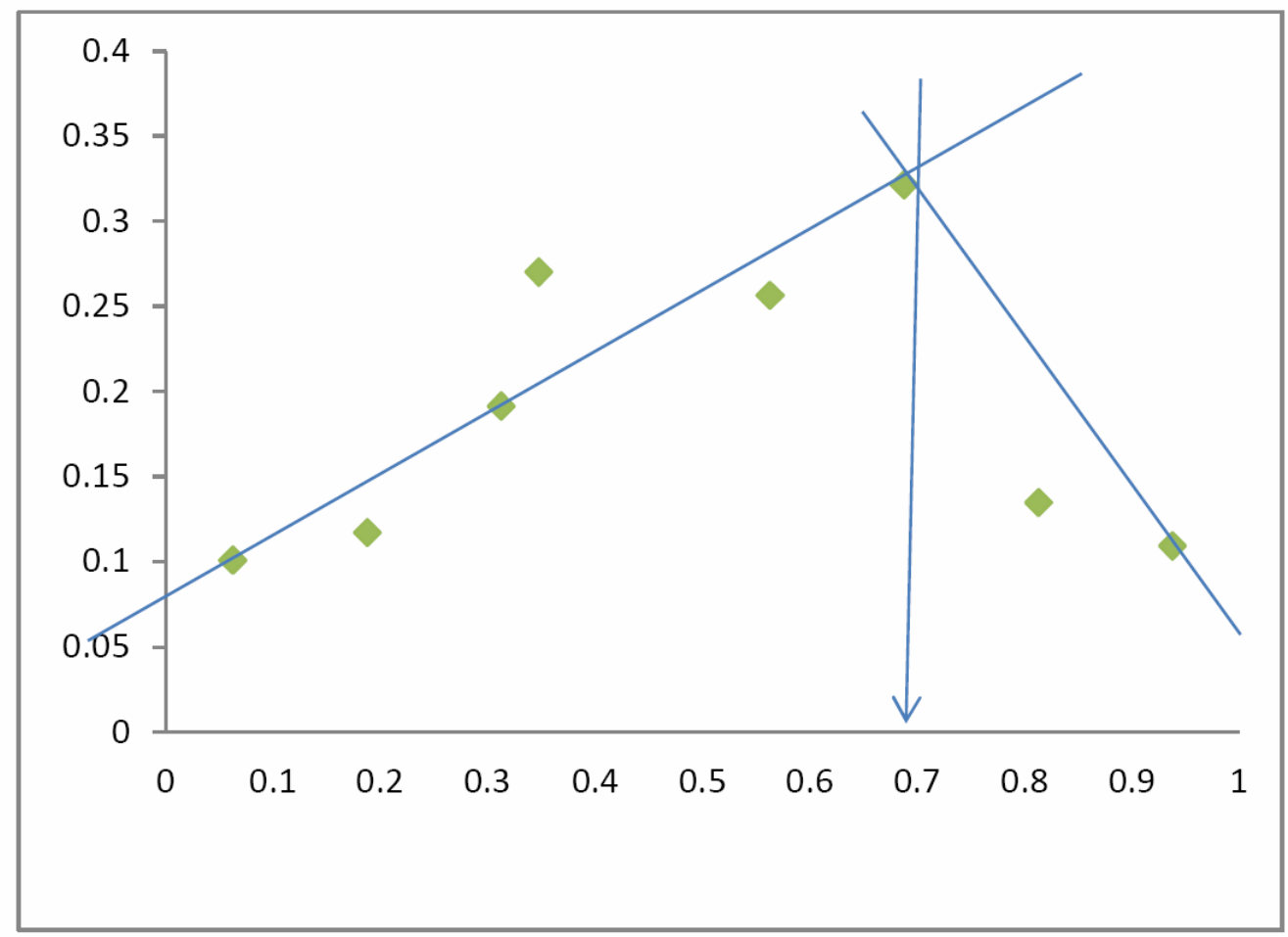

Figure 1. $\mathrm{Cr}^{2+}$ ion absorbance against mole fraction. 


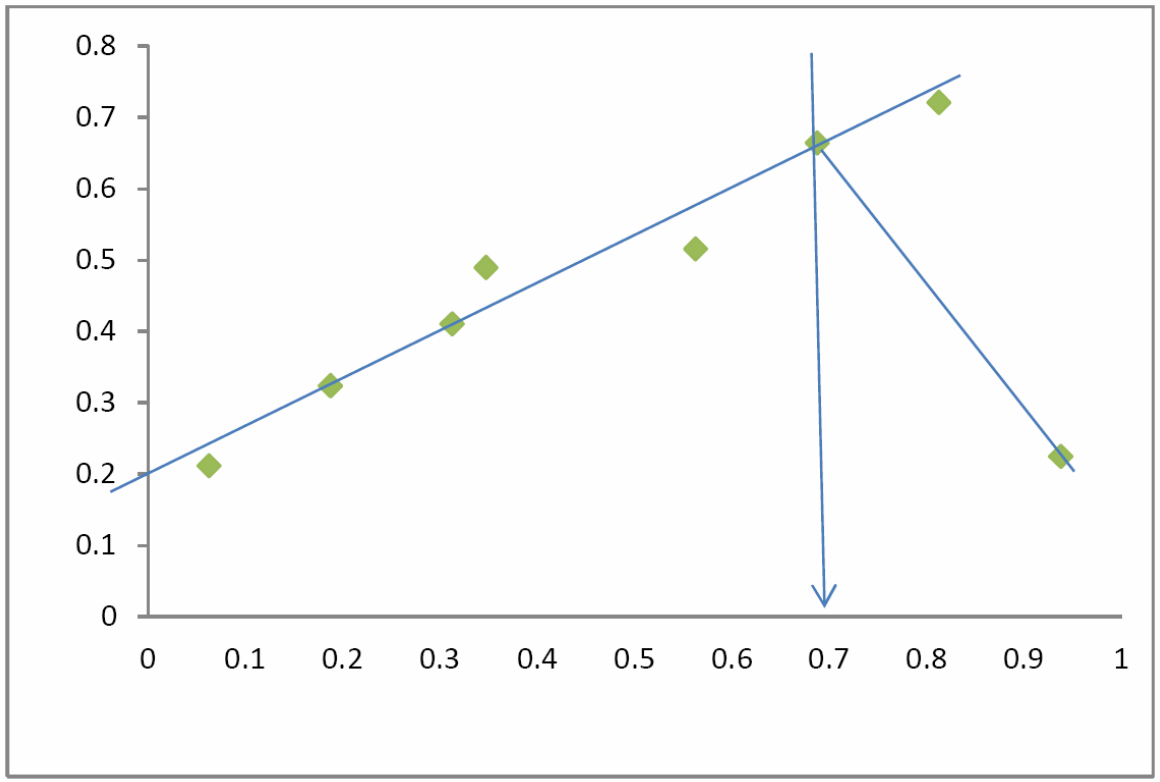

Figure 2. $\mathrm{Mn}^{2+}$ ion absorbance against mole fraction.

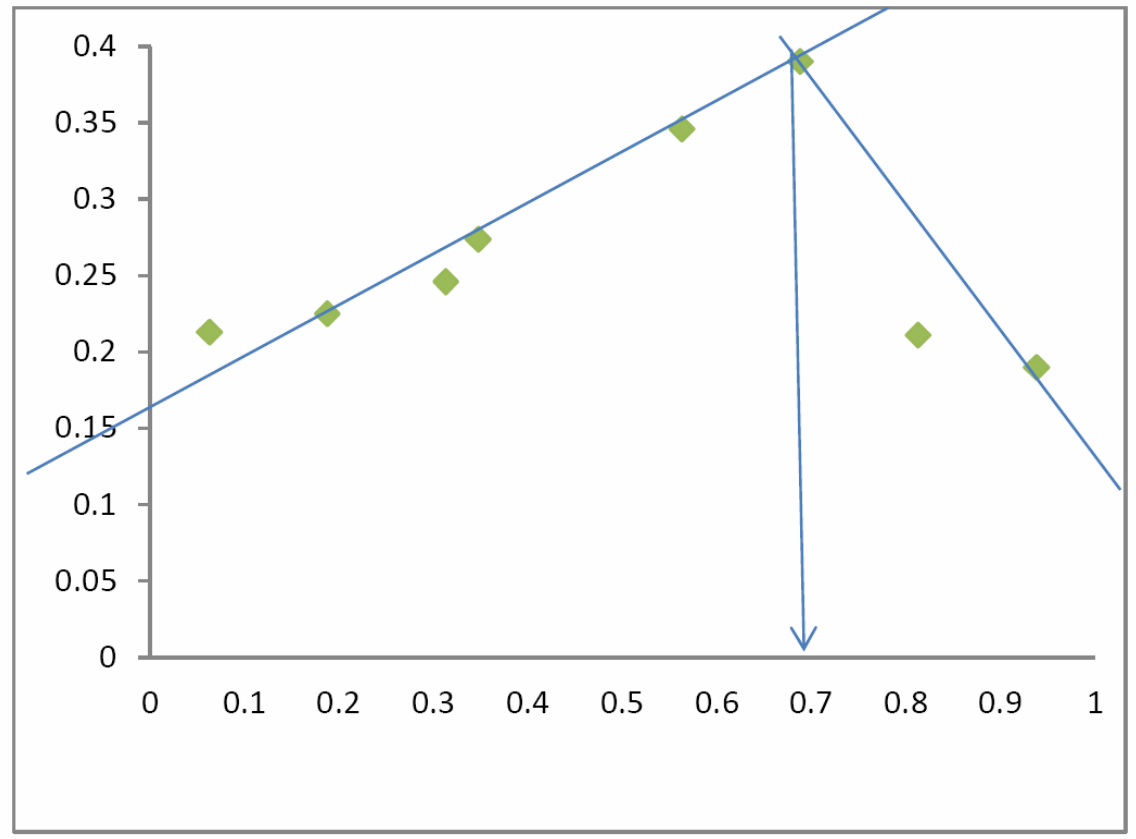

Figure 3. $\mathrm{Co}^{2+}$ ion absorbance against mole fraction. 
The antibacterial activity of the schiff base and metal complexes was carried out on three bacteria isolates, (Staphylococcus aureus, Streptococcus pnemoniae and Eschericia coli) using well diffusion method by taking DMSO as solvent (Table 3.10). The result shows that both the ligand and metal complexes are found to be moderately effective against all tested bacteria, but the metal complexes exhibit higher antibacterial activity than the Schiff base and the activity increase with increase in concentration, this is probably due to chelation in the metal complexes. The Schiff base show activity against Staphylococcus aureus and Eschericia coli at all concentrations, but found to be active only at $(60 \mu \mathrm{g}$ and $30 \mu \mathrm{g})$ concentrations against Staphylococcus aureu. $\mathrm{Cr}$ (II) complex was found to be effective only at high concentration $(60 \mu \mathrm{g})$ against Streptococcus pnemoniae, Co(II) complex was also effective at $(60 \mu \mathrm{g}$ and $30 \mu \mathrm{g})$ concentration, whie the complex of $\mathrm{Mn}(\mathrm{II})$ is active at all concentrations. In Eschericia coli, the complexes of $\mathrm{Mn}$ (II) and $\mathrm{Co}$ (II) are active at all concentrations. $\mathrm{Cr}$ (II) complex is effective at $(60 \mu \mathrm{g}$ and $30 \mu \mathrm{g}$ ). However, in comparison to the standard drugs antibacterial activities of the Schiff base as well as the complexes is low.

Antifungal studies were carried out by well diffusion technique on potato dextrose agar against three fungal isolate Aspergillus fumigatus, Aspergillus flavus and Candida albicans (Table 3.11). The result of anti-fungal screening for the Schiff base and metal complexes revealed that the Schiff base and corresponding metal (II) complexes show an activity against Aspergillus fumigatus isolate and the activity increase with increase in concentration, Also, the Schiff base and the metal (II) complexes are all show high activity against Aspergillus flavus at all concentrations. In Candida albicans, the Schiff base and the $\mathrm{Mn}$ (II) complex shows an appreciable activity at all concentrations. The $\mathrm{Cr}$ (II) complex is inactive at all concentrations while the $\mathrm{Co}(\mathrm{II})$ complex is active at $(60 \mu \mathrm{g})$ concentration only.

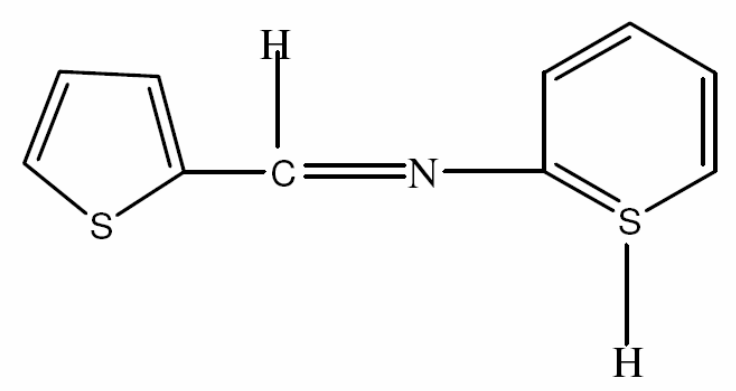

Figure 4.1. Proposed structure of the ligand. 


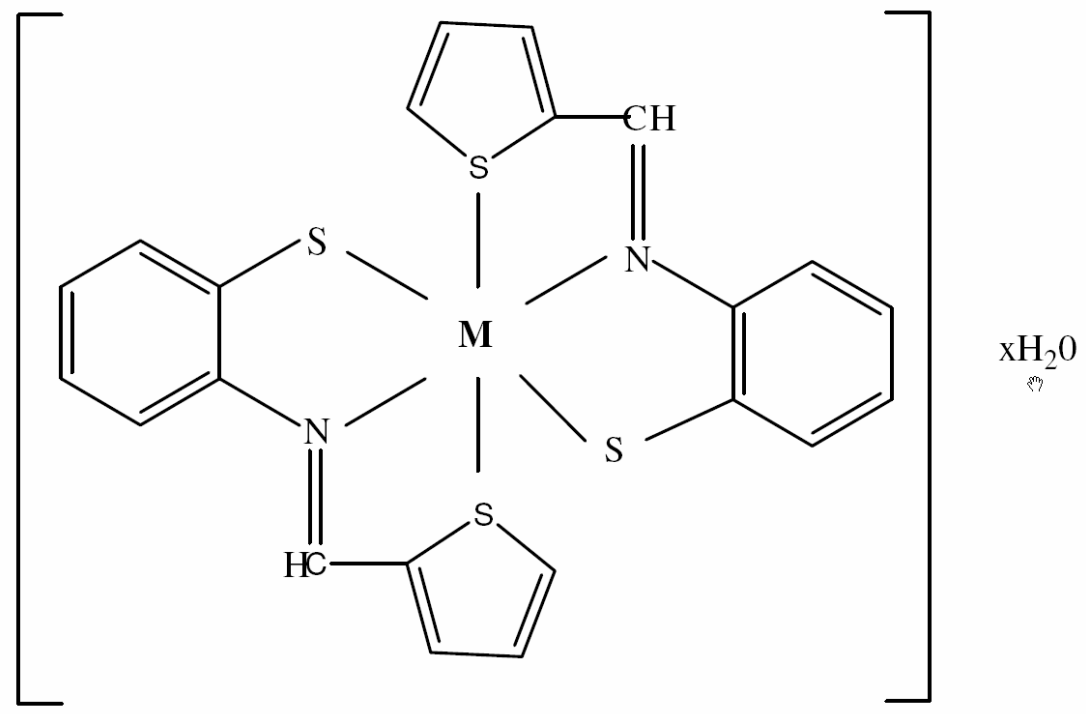

Figure 4.2. Proposed structure of the complex.

\section{Conclusion}

The Schiff base and its metal complexes of $\mathrm{Cr}$ (II), $\mathrm{Mn}$ (II) and $\mathrm{Co}$ (II) have been synthesized and studied by various analytical techniques. Job's method of Continuous variation shows that the metal-ligand ratio in all the complexes is 1:2. All the complexes are non-electrolytes in DMSO solvent. The decomposition temperature of the metal (II) complexes indicated that complexation has taken places. Based on electrical conductivity data, $\mathrm{Cr}(\mathrm{II}), \mathrm{Mn}(\mathrm{II}), \mathrm{Co}$ (II) Schiff base complexes are paramagnetic. The antimicrobial studies of the Schiff base and its metal(II) complexes reveals that the metal(II) complexes show better activity when compared to that of the ligand.

\section{References}

[1] H. Adamu, Synthesis and characterization of N(1-morpholinobenzyl semicarbazide metal complex, Unpublished M.Sc. dissertation, Department of Pure and Industrial Chemistry, Bayero University, Kano, 2009.

[2] Ali Mohammed Yimer, Chemical synthesis, spectral characterization and antimicrobial studies on complexes of $\mathrm{Ni}(\mathrm{II}), \mathrm{Cu}(\mathrm{II})$ and $\mathrm{Zn}$ (II) with N,N-di(ohydroxybenzenoylmethylene) ethylenediamine, American Journal of Bioscience 2(6-1) (2014), 22-34. 
[3] H.N. Aliyu and H. Adamu, Synthesis and characterization of N-(I-Morpholinobenzyl) simicarbazide Manganese (II) and Iron (II) complexes, Bayero Journal of Pure and Applied Science 2(2) (2009), 143-148. https://doi.org/10.4314/bajopas.v2i2.63802

[4] H.N. Aliyu and I. Ado, Studies of Mn (II) and Ni (II) complexes with Schiff base derived from 2-amino benzoic acid and salicylaldehyde, Bayero Journal of Pure and Applied Science 23 (2011), 245-249. https://doi.org/10.4314/bajopas.v3i1.58803

[5] S. Arulmuragan, H.P. Kavitha and R.B. Venkatraman, Biological activities of Schiff base and its complexes, Rasayan Journal of Chemistry 3 (2010), 385-410.

[6] M.A. Ashraf, K. Mahmood, Abdul Wajid, M.J. Maah and I.B. Yusoff, Synthesis, characterization and biological activity of Schiff bases, 2011 International Conference on Chemistry and Chemical Process, IPCBEE, Vol. 10, Singapore, 2011, pp. 256-264.

[7] S. Bootwala, M. Tariq, S. Somasundaran and K. Aruna, Synthesis, spectroscopic and biological characterization of some transition metal complexes with ethyl 2-\{[(2E, $3 \mathrm{Z})-4-$ hydroxypent-3-en-2-ylidene ] amino $\}-4, \quad 5, \quad 6$, 7-tetrahydro-1-benzothiophene-3carboxylate, International Journal of Pharmacy and Biological Sciences 3 (2013), 345354.

[8] C. Clarkson, V.J. Maharaj, N.R. Crouch, O.M. Grace, P. Pillay, M.G. Matsabisa, N. Bhagwandin, P.J. Smith and P.I. Folb, In vitro antiplasmodial activity of medicinal plants native to or naturalized in South Africa, J. Ethnopharm. 92 (2004), 177-191. https://doi.org/10.1016/j.jep.2004.02.011

[9] G. Devi, Studies on transition metal complexes of schiff bases derived from amino acids, Thesis, Department of Chemistry, University of Calicut, 2002.

[10] P. Goel, D. Kumar and S. Chandra, Schiff's base ligands and their transition metal complexes as antimicrobial agents, J. Chem. Bio. Phy. Sci. Section A 4 (2014), 19461964.

[11] M.A. Hadi, Preparation and Characterization of Some Transition Metal Complexes with Schiff base ligand, Journal of Kerbala University 7 (2009), 52-57.

[12] J. Iqbal, M. Imran, S. Iqbal and S. Latif, Synthesis, Characterization and Biological Studies of 2-[phenylmethyl amino]benzoic acid and its complexes with $\mathrm{Co}(\mathrm{II}), \mathrm{Ni}(\mathrm{II})$, $\mathrm{Cu}(\mathrm{II})$ and $\mathrm{Zn}(\mathrm{II})$, Journal of Chem. Soc. Pakistan 29 (2007), 151-154.

[13] K. Mounika, B. Anupama, J. Pragathi and C. Gyanakumari, Synthesis, characterization and biological activity of a Schiff base derived from 3-ethoxy salicylaldehyde and 2amino benzoic acid and its transition metal complexes, Journal of Scientific Research 2(3) (2010), 513-524. https://doi.org/10.3329/jsr.v2i3.4899 
[14] S.A. Khan, A.M. Asiri, S. Kumar and K. Sharma, Green synthesis, antibacterial activity and computational study of pyrazoline and pyrimidine derivatives from 3-(3,4-dimethoxyphenyl-1-(2,5-dimethyl-thiophen-3-yl)-propenone, European Journal of Chemistry 5 (2014), 85-90. https://doi.org/10.5155/eurjchem.5.1.85-90.789

[15] A.A. Muhammed, M. Karamat and W. Abdul, Synthesis, Characterization and Biological Activity of Schiff bases, International Conference on Chemistry and Chemical Process IPCBEE Vol. 10, IACSIT Press, Singapore, 2011.

[16] T. Mahmud, Synthesii and characterization of amino acid schiff base and their complexes with copper(II), University of Manchester, Chemistry, Manchester, UK, 2010.

[17] G.G. Mohamed, M.M. Omar and A.M. Hindy, Metal complexes of Schiff bases: preparation, characterization, and biological activity, Turk. J. Chem. 30 (2006), 361-382.

[18] B.N. Meyer, R.N. Ferrigni, J.E. Putnam, L.B. Jacobsen, D.E. Nichols and J.L. McLaughlin, Brine shrimp: a convenient general bioassay for active plant constituents, Planta Medica 45 (1982), 31-34. https://doi.org/10.1055/s-2007-971236

[19] A. Prakash and A. Adhikari, Application of Schiff base and Their Metal Complexes-A Review, International Journal of Chem. Tech. Research 3 (2011), 1891-1896.

[20] B.K. Panda and A. Chakravorty, Spectroscopic properties of inorganic and organometallic compounds, Journal of Organometallic Chemistry 690 (2005), 31693175 .

[21] M. Rahmatullah, S. M. I. Sadeak, S. C. Bachar, M.T. Hossain, A. Montaha Al-mamun, N. Jahan, M.H. Chowdhury, R. Jahan, D. Nasrin, M. Rahman and S. Rahman, Brine Shrimp toxicity study of different Bangladeshi medicinal plants, Advances in Natural and Applied Sciences 4(2) (2010), 73-163.

[22] Rani Anita, Manoj Kumar, Rajshree Khare and Hardeep S. Tuli, Schiff bases as an antimicrobial agent: A review, Journal of Biological and Chemical Science 2(1) (2015), 62-91.

[23] Sadia Afrin Dalia, Farhana Afsan, Md. Saddam Hossain, Md. Nuruzzaman Khan, C.M. Zakaria, Md. Kudrat-E-Zahan and Md. Mohsin Ali, A short review on chemistry of Schiff base metal complexes and their catalytic application, International Journal of Chemical Studies 6(3) (2018), 2859-2866.

[24] S. Sani and M.A. Kurawa, Synthesis, characterization and antimicrobial studies of $\operatorname{Mn}(\mathrm{II})$ complex with N-salicyl-O-hydroxyphenyleneiminato Schiff base ligand, ChemSearch Journal 7(2) (2016). 
[25] U. Sani and S.A. Dailami, Synthesis, characterization, antimicrobial activity and antioxidant studies of Metal(II) complexes of Schiff base derived from 2-hydoxy-1 napthaldehyde and hydrazine monohydrate, ChemSearch Journal 6(2) (2015), 35-41.

[26] Taghreed M. Musa, Synthesis, characterization and antimicrobial activity of some transition complexes with new Schiff base derived from Saccharine, International Research Journal of Pure and Applied Chemistry 11(2) (2016), 1-5. https://doi.org/10.9734/IRJPAC/2016/23188

[27] Yusuf Yunusa, Synthesis, characterization and antimicrobial activity of some metal(II) Schiff base complexes, Unpublished M.Sc. dissertation, Department of Pure and Industrial Chemistry, Bayero University, Kano, 2017. 